\title{
The Effects of Rauwolfia Vomitoria Extract on the Liver Enzymes of Carbon Tetrachloride Induced Hepatotoxicity in Adult Wistar Rats.
}

\author{
Ezejindu D.N. ${ }^{1}$, Okafor I. A. ${ }^{1}$, Anibeze C.I.P. ${ }^{2}$, Uloleme G.C. ${ }^{3}$ \\ ${ }^{I}$ Department of Anatomy, College of Health Sciences, Nnamdi Azikiwe University, Nnewi Campus, Anambra \\ State, Nigeria. \\ ${ }^{2}$ Department of Anatomy, , College of Health Sciences, Abia State University, Uturu, Abia State Nigeria. \\ ${ }^{3}$ Department of Anatomy, College of Health Sciences, Imo State University, Owerri Imo State, Nigeria.
}

\begin{abstract}
Rauwolfia vomitoria is a natural medicinal plant which has been used over the years for the treatment of various ailments. The effects of extract of rauwolfia vomitoria on liver enzymes of carbon tetrachloride induced hepatotoxicity were observed in adult wistar rats weighing between $120 \mathrm{~g}$ and $190 \mathrm{~g}$. They were divided into four groups $A, B, C$ and $D$ of six rats each. Group $A$ served as the control and received $0.41 \mathrm{ml}$ of distilled water. The experimental groups $B, C$ and $D$ received different doses of drugs as follows : group $B$ received $0.50 \mathrm{ml}$ of rauwolfia vomitoria extract, group $C$ received $0.5 \mathrm{ml}$ of carbon tetrachloride and group $D$ received $0.41 \mathrm{ml}$ of carbon tetrachloride $+0.4 \mathrm{ml}$ of rauwolfia vomitoria extract. The drugs were administered once in a day using intubation method for a period of twenty one days. Twenty four hours after the last administration, the animals were anaesthetized under chloroform vapour and dissected. liver tissues were removed and weighed. Blood samples were collected by cardiac puncture and Serum samples were separated from clot by centrifugation using bench top centrifuge. Activities of serum aspartate aminotransferase, alanine aminotransferase and alkaline phosphatase were determined using randox kit method. The relative liver weight for carbon tetrachloride treated group were significantly higher $(p<0.001)$ than the control and groups $B$ and D. serum aspartate aminotransferase, alanine aminotraansferase and alkaline phosphate level of group $C$ were statistically higher $(p<0.001)$ than the control. The extract exhibited a liver protective effect against carbon tetrachloride induced hepatotoxicity.
\end{abstract}

Keywords: Liver enzymes, , Liver weight, Rauwolfia vomitoria, Wistar rats.

\section{Introduction}

Liver is the key organ regulating homeostasis in the body. It is involved with almost all the biochemical pathways related to growth, fight against disease, nutrient supply, energy production and reproduction. Because of its unique metabolism and relationship to the gastrointestinal tract, the liver is an important target for toxicity produced by drugs, xenobiotics and oxidative stress. ${ }^{[6]}$ More than 900 drugs, toxins and herbs have been reported to cause liver injury and drugs account for $20-40 \%$ of all instances of fulminant liver failure. ${ }^{[1]}$

From 1931, Indian doctors researched on possible utilization of Rauwolfia vomitoria in neuropsychiatry. The extract from this plant was first extracted by Swiss chemists in 1952 and becomes the first natural neuroteptic. Today, this plant is still the source of a lot of drugs used in psychiatry ${ }^{[5]}$. In traditional medicine, the roots and leaves of Rauwolfia vomitoria are brewed as tea and used in humans for treatment of hypertension, insanity, snakebite and cholera ${ }^{[9]}$.

One of the plants of medicinal value from the humid tropics is Rauwolfia Vomitoria. It is traditionally used in treatment of variety of ailment such as snakebites, fever and nervous disorders. In the absence of reliable liver protection drugs in modern medicine, a large number of medicinal preparations are recommended for the treatment of liver disorders and quite often claimed to offer significant relief. Attempts are being made globally to get scientific evidences for these traditionally reported herbal drugs. This scenario provides a severe necessity to carry out research in the area of hepatotoxicity ${ }^{[1]}$.

Hence, this study aims at painstakingly investigating the effects of rauwolfia vomitoria extract on liver enzymes of carbon tetrachloride induced hepatotoxicity in adult Wistar rats.

\subsection{Breeding Of Animals}

\section{Materials And Methods}

Twenty four Wistar rats were purchased from the animals house of the Anatomy Department, University of Calabar, Cross River State, Nigeria and bred in the Animal house of University of Uyo Akwa Ibom State. They were allowed for a period of five days for acclimatization under normal temperature $\left(27^{0} \mathrm{C}\right.$ - 
$30^{\circ} \mathrm{C}$ ) before their weights were taken. They were fed ad-libitum with water and guinea feed pallets from Agro feed mill Nigeria Ltd.

\subsection{Drug Preparation}

Rawolfia vomitoria leaves were collected from Eket in Akwa Ibom State and was dried in an oven at a temperature of $50^{\circ} \mathrm{C}$ and crushed using laboratory blender. Extraction was done using ethanol. Ethanol was poured into the grinded leafs of Rauwolfia vomitoria and was allowed to stay for twenty four hours. It was filtered into a stainless basin with a white cloth and placed in a water bath so as to dry up the ethanol. $300 \mathrm{mg}$ of this extract $/ \mathrm{kg}$ body weight was dissolved in $10 \mathrm{mls}$ of distilled water and administered to the animals.

Carbon tetrachloride was obtained from the Department of Biochemistry, University of Calabar, Cross Rivers State, Nigeria.

\subsection{Experimental Protocols}

The twenty four animals were weighed and allocated into six groups of four animals each. The groups were designated as groups A, B, C, and D. Group A animals served as the control and received $0.35 \mathrm{ml}$ of distilled water. The experimental groups B, C and D received different doses of drugs as follows: Group B received $0.55 \mathrm{ml}$ of extract of Rauwolfia vomitoria, Group C received $0.41 \mathrm{ml}$ of carbon tetrachloride $\left(\mathrm{CCL}_{4}\right)$, Group D received $0.8 \mathrm{ml}$ of extract $+0.41 \mathrm{ml}$ of carbon tetrachloride. The drugs were administered once in a day between the hours of $12-3.30 \mathrm{pm}$ for a period of twenty one days. The drugs were administered orally using intubations method. After the twenty first day, the animals were weighed and their weight recorded.

Twenty four hours after the last administration, the animals were anesthetized under chloroform vapour and were dissected. Blood samples were collected by cardiac puncture using sterile syringes with needles. Blood for serum preparation was collected into sterile plain tubes without an anti-coagulant. Serum samples were separated from the clot by centrifugation at 3,000rpm for 5minutes using bench top centrifuge (MSE, Minor, England). Serum samples were separated into sterile plain tubes and were stored in the refrigerator for analysis. Liver tissues were removed from the animals and weighed. The activities of serum aspartate aminotransferase (AST), alanine aminotransferase (ALT) and alkaline phospotase (ALP) were determined using randox kit method.

\subsection{Morphometric Analysis Of Body Weights}

\section{Results}

The result obtained from calculation of initial, final and weight change of the various groups are presented in table 1.0 below

Table 1,0: Comparison of mean initial and final body weight and weight change in all the groups (A,B,C \&D)

(Mean \pm SEM given for each measurement)

\begin{tabular}{|l|l|l|l|l|l|l|}
\hline & GP. A & GP. B & GP. C & GP. D & F-RATIO & PROB.OF SIG. \\
\hline INITIAL BODY WT. & $104.50 \pm 4.79$ & $111.75 \pm 4.64$ & $164.75 \pm 7.63$ & $129.50 \pm 8.96$ & 68.230 & $<0.0001$ \\
\hline FINAL BODY WT. & $112.50 \pm 6.60$ & $121.50 \pm 10.66$ & $133.25 \pm 8.53$ & $137.75 \pm 10.01$ & 30.510 & $<0.0001$ \\
\hline WT. CHANGE & $8.00 \pm 7.70$ & $9.75 \pm 6.50$ & $31.50 \pm 15.08$ & $8.25 \pm 5.67$ & 16.150 & $<0.0001$ \\
\hline
\end{tabular}

The final body weight for group A (Control), groups B, C, and D showed a statistically significant decrease $(\mathrm{P}<0.001)$

The final body weight for group $\mathrm{C}$ treated with carbon tetrachloride was significantly higher $(\mathrm{P}<0.001)$ than the control and other experimental groups (B and D) animals. The weight change for group $\mathrm{C}$ showed a statistically increase compared with the control and other experimental groups $(\mathrm{P}<0.001)$.

Figure 1.0 are the bar chat representation of the mean initial and final body weight. After the administration, the weight of animals in group A (control) and group B, and C increased statistically. 
Figure 1.0 is the bar chat representation of the mean initial and final body weight.

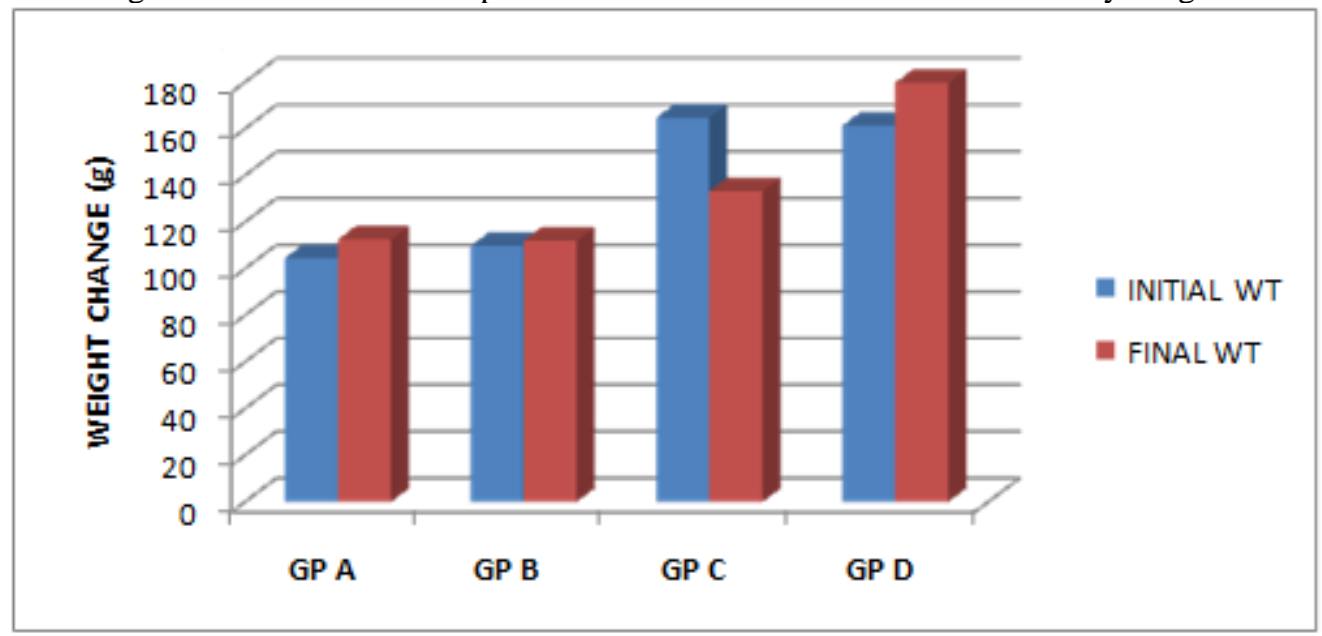

\subsection{Morphometric Analysis Of Liver Weights}

The results obtained from calculations of relative liver weight of the various groups are presented in table 2.0. The relative liver weight for group $\mathrm{C}$ (carbon tetrachloride administered) were significantly higher $(\mathrm{P}<0.001)$ than that of the group $\mathrm{A}$ (control) and other experimental groups $(\mathrm{B}$, and $\mathrm{D})$. The values for groups B and D were similar to the group A (control)

Table 2.0: comparison of mean relative liver weight for group A (control) and experimental groups (B,C and D) (Mean \pm SEM given for each measurement)

\begin{tabular}{|l|l|l|l|l|l|l|}
\hline & GP. A & GP. B & GP. C & GP. D & F-RATIO & PROB. OF SIG. \\
\hline LIVER WT. & $4.79 \pm 0.045$ & $4.66 \pm 0.161$ & $7.33 \pm 0.625$ & $4.72 \pm 0.070$ & 53.84 & $<0.0001$ \\
\hline
\end{tabular}

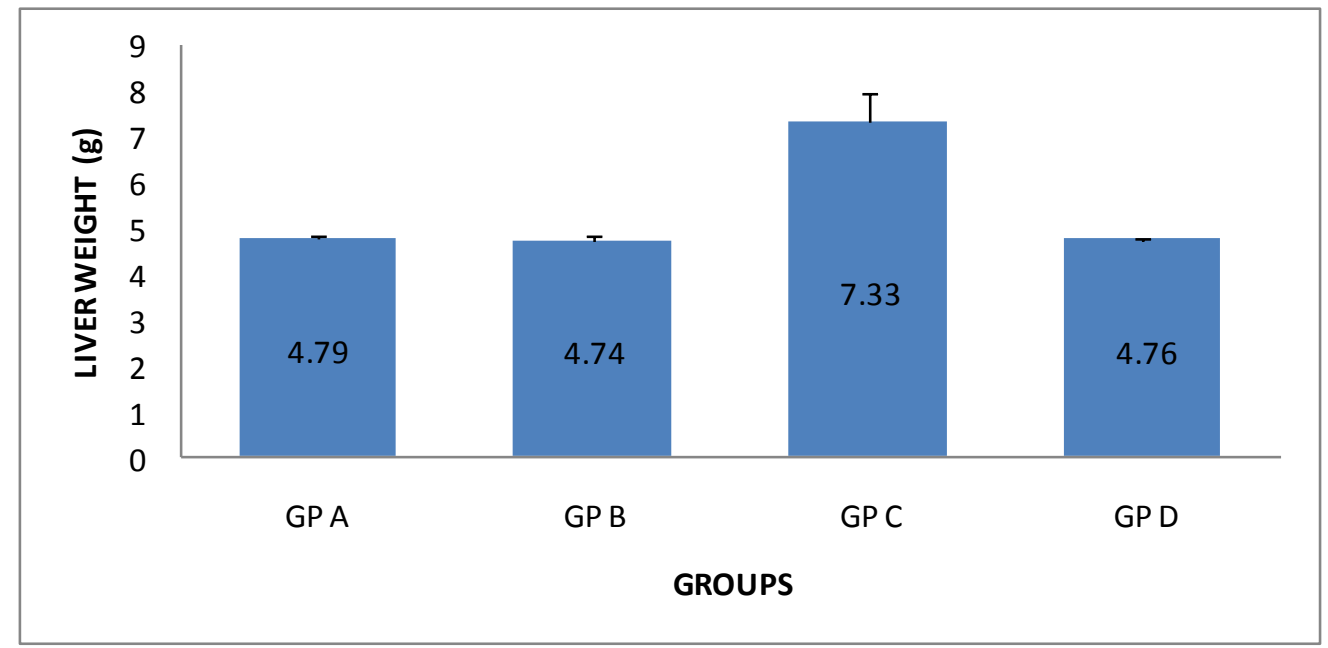

FIG 2.0. The bar chart representation of the relative liver weight of the various groups.

3.3 Activities of serum levels of Aspartate aminotransferase (AST), Alanine aminotransferase (ALT) and Alkaline phosphotase (ALP)

\begin{tabular}{|l|l|l|l|l|l|l|}
\hline & (Mean -+SEM given for each measurement) \\
\hline $\begin{array}{l}\text { ASPARTATE } \\
\begin{array}{l}\text { AMINOTRANSE- } \\
\text { FERASE (AST) }\end{array}\end{array}$ & $78.80 \pm 28.55$ & $69.75 \pm 13.51$ & $\begin{array}{l}246.66 \pm 5.7 \\
7\end{array}$ & $68.66 \pm 5.77$ & 60.04 & $<0.0001$ \\
\hline $\begin{array}{l}\text { ALANINE } \\
\text { AMINOTRANSE } \\
\text { FERASE (ALT) }\end{array}$ & $50.00 \pm 15.74$ & $46.50 \pm 11.12$ & $95.33 \pm 9.01$ & $41.33 \pm 8.08$ & 12.30 & $<0.0001$ \\
\hline $\begin{array}{l}\text { ALKALINE } \\
\text { PHOSPHOTASE (ALP) }\end{array}$ & $481.39 \pm 31.22$ & $397.90 \pm 37.83$ & $673 \pm 46.75$ & $436.20 \pm 161.29$ & 7.58 & $<0.0012$ \\
\hline
\end{tabular}


From the results obtained from calculations of aspartate aminotrasferase (AST), alanine aminptransferase (ALT) and alkaline phosphotase (ALP), there were a significant decrease $(\mathrm{P}<0.001)$ in the AST activity levels at all does of the drugs relative to the control (A) except in group C treated with carbon tetrachloride $\left(\mathrm{CCL}_{4}\right)$. The group $\mathrm{C}$ activity level statistically were significantly higher $(\mathrm{P}<0.001)$ than the control (A) and other groups.

The alanine aminitrasferase (ALT) activity levels showed a significant decrease $(\mathrm{P}<0.001)$ in groups $\mathrm{B}$, and $\mathrm{D}$ relative to the control (A) except in group $\mathrm{C}$ treated with carbon tetrachloride $\left(\mathrm{CCL}_{4}\right)$. The alkaline phosphotase (ALP) level in group C were significantly higher than the control group (A) and other groups.

The alkaline phosphotase (ALP) activity levels in groups $B$, and D were significantly lower $(P<0.001)$ than the control (A). The alkaline phosphotase activity levels in group $\mathrm{C}$ were significantly higher $(\mathrm{P}<0.001)$ than the control (A) and other groups

\section{Discussion}

The results of this study agree with previous researchers that carbon tetrachloride has toxicological effect on the liver (enzymes) of wistar rats . There were no significant difference $(\mathrm{P}<0.001)$ in the serum and tissues levels of AST, ALT and ALP in groups B and D compared with the control as shown in table 2,0. There were significant difference $(\mathrm{P}<0.001)$ in the serum and tissues levels of AST, ALT and ALP in group C compared with the control and groups B and D. These results indicated that the extract from Rauwolfia vomitoria did not bring about cellular damage in the liver during the experimental period. Enzyme activities in the serum and tissues are often used as "maker" to ascertain toxic effects of administered foreign compounds to experimental animals ${ }^{[3]}$. ALP is a membrane bound enzyme ${ }^{[10]}$ while ALT and AST are cytosolic enzymes ${ }^{[2]}$. These enzymes are highly concentrated in the liver and kidney and are only found in serum in significant quantities when the cell membrane becomes leaky and even completely ruptured ${ }^{[4,8]}$. A rise in serum level or decrease in tissue level of these intracellular enzymes is an index of damage to the liver cells ${ }^{[7]}$.

Observation of the body weight difference in groups reveals gradual increase in weight of animals for the control group A. This could have been physiological as the only substance they were exposed to was water and food. Comparing the results of weight difference reveals severe loss of weight by the carbon tetrachloride exposed group. This is probably as a result of loss of appetite by the animals in the group. The groups that were treated with extract of Rauwolfia vomitoria only, extract of Rauwolfia vomitoria + carbon tetrachloride, showed increase in weight which is similar to the control group. Extract of Rauwolfia vomitoria in this instance functions primarily as a dietary supplement enhancing growth. Previous researches cited in literatures of Rauwolfia vomitoria did not state pre and post experimental weight, hence weight changes were not determined in their works.

The relative weights of the organ also showed significant differences in groups. There was relative increase in liver weight for the carbon tetrachloride exposed animals compared to the control. This organ weight increase was irrespective of the fact that there was total body weight loss. This could have been pathological and one may deduce that the increase in liver weight was not growth but inflammation. Antioxidant properties of Rauwolfia vomitoria could have been responsible for the control or prevention of inflammation in the groups treated with them.

The animals in group $\mathrm{D}$ gives a particularly interesting observation about the dynamics of reactions to the presence of various substances in our systems. On administration of extract of Rauwolfia vomitoria respectively to the groups, the animals showed increase in overall body weight similar to that of the control. Administration of extract of Rauwolfia vomitoria alone did not cause weight loss to the animals compared with the animals in control group Bythese observation one may deduce that administration of extract of Rauwolfia vomitoria may boost the tolerance capacity for carbon tetrachloride induced toxicity

\section{Conclusion}

The extract of Rauwolfia vomitoria did not induce adverse alterations in biochemical parameters of serum aspartate aminitransferase (AST), serum alanine aminotrasferase (ALT) and Alkaline phosphotase (ALP) and no histopathological lessons was observed in the liver tissues of the rats. This study has demonstrated the potential ability of Rauwolfia vomitoria to protect against carbon tetrachloride induced toxicity in the liver enzymes of rats. The findings of this study suggests that Rauwolfia vomitoria administered to individuals exposed to carbon tetrachloride poisoning could provide some protection against carbon tetracholoride effects on the liver enzymes 


\section{References}

[1]. Anusha M., M. Venkateswarlu, V. Prabhakaran,1 S. Shareen Taj, B. Pushpa Kumari, and D. Ranganayakulu Hepatoprotective activity of aqueous extract of Portulaca oleracea in combination with lycopene in ratsIndian Journal of Pharmacology. Sep-Oct $2011 ; 43(5) 563$

[2]. Christen P. and D. E. Metzler. (1985).Transaminases . ISBN-10: 0471085014 |ISBN-13: 9780471085010

[3]. Coodley Eugene L. (1970). Diagnostic Enzymology. Submit query lea and febiger publications. ISBN 0812100441

[4]. Cotran R., Kumar V and Robins S (1989). Robin's pathological basis of disease. 4th edn. W.B Saunders Co. Harcourt. Pp: $212-217$.

[5]. Hansel R. (1968). Flavonoide, endaugestacting and vertedung ulcer daspflama system, wirking pharm press, China,pas. 6: $121-124$.

[6]. Jaeschke H, Gores GJ, Cederbaum AI, Hinson JA, Pessayre D, Lemasters JJ. Mechanisms of hepatotoxicity. Toxicol Sci. 2002;65:166-76. [PubMed]

[7]. Moss D.W and Rosalki SBv(1996). Enzyme Tests in Diagnosis. 2nd Edition. Edward Arnold. London. Pp: $201-213$.

[8]. Ngaha EO (1981). Renal effects of potassium dichromate in the rat: composition of urinary excretion with corresponding tissue pattern. Gen Pharmacol 12: 291-358.

[9]. Shavarov Z. (1965). The healing powers of herbs with special reference to obstetrics and gynaecology 43-44.

[10]. ${ }^{0}$ Wright P. J. and D. J. Plummer (1974). The use of urinary enzyme measurements to detect renal changes caused by nephrotoxic compounds. Biochem. Pharmacol., 12:65-68. 